\title{
Business engineering incubators: a cooperation case for cluster's development
}

\author{
Antônio Honorato de Oliveira ${ }^{\text {a* }}$, Fernando Augusto Silva Marins ${ }^{\mathrm{a}}$, Maurício César Delamaro ${ }^{\mathrm{a}}$ \\ aUniversidade Estadual Paulista Júlio de Mesquita Filho, Guaratingueta, SP, Brasil \\ *antoniohonoratooliveira@yahoo.com.br
}

\begin{abstract}
Paper aims: To present the performance and contributions of a business incubator that acts as a link between the members of an industrial cluster and a higher education institution that acts in the field of engineering.

Originality: Most articles focus on incubators from the point of view of internal activities, the nature of incubation processes, and financing intermediary programs for nascent businesses. This work aimed to broaden the traditional approach of the academic constructs researched on the role of business incubators by bringing the contributions of one of the largest Brazilian business incubators to the formation and development of an industrial cluster.
\end{abstract}

Research method: The results represent the extract from a case study. The inductive method of basic research with a combined approach is applied for exploratory and descriptive purposes, using documentary analysis and field research.

Main findings: This paper addresses a successful integration between an engineering school and the business environment through its incubator while summarizes the trajectory of this incubator, and highlights, among other contributions to the local industrial cluster, the significant survival rate of its graduated companies.

Implications for theory and practice: Coordinated actions among members of the triple helix model are evidenced in this paper and may form the basis for similar experiments involving government agencies, educational institutions and the industrial environment.

\section{Keywords}

Triple helix model. Business engineering incubator. Clusters. Innovation. Development.

How to cite this article: Oliveira, A. H., Marins, F. A. S. Ct Delamaro, M. C. (2018). Business engineering incubators: a cooperation case for cluster's development. Production, 28, e20180001. https://doi.org/10.1590/0103-6513.20180001.

Received: Feb. 1, 2018; Accepted: July 15, 2018.

\section{Introduction}

ldentifying the performance and contributions of a business incubator that acts as a link between Triple Helix's (TH) members and an Industrial Cluster was the subject of this case study. It presents the incubator's trajectory and its results as an integral part of the TH's model, established at Brazilian Electronic Valley, located in the south of the State of Minas Gerais, Brazil.

In this sense, the TH Model is perceived as a set of initiatives, commitments and effective actions promoted by teams representing the communities, namely organizations, educational institutions, and government, lined up with socioeconomic development, progress, and continued existence of communities where they are established.

Consistent with the experts' opinions (Greco, 2015, p. 91) it is perceived necessary [...] insert greater demands on the students training and preparation process of in universities, with better teachers, coaching and practical education, less memorization and multiple choice tests, more reading and discussion and less repetition and standardization, much more entrepreneurship than studying content of little use after graduation.

In addition, the state and the educational institutions are expected to take effective action in the form of transitory links of knowledge and practice. In this scenario, it can be seen business incubators as embryo 
developers capable of structuring and strengthen the initiatives of students and entrepreneurs with greater survival probability and success in the market.

Thus, this research is justified by the effort to verify and bring to the public, especially for all researchers who are interested in examples of study initiatives based on the TH, whose results indicate assertiveness, both in the form of structuring and the results recommended by the Global Entrepreneurship Monitor (Greco, 2015).

In advocating the regional development agencies dominance as guardians of local innovation capacity and as leading agencies for stakeholder engagement and value capture, Danson \& Todeva (2016) suggests that the efficiency of regional authorities comes from their knowledge and practice of intense TH interactions. These authors emphasize that the United Kingdom's regions that have lost their regional authorities are marked in the literature as they have presented difficulties in generating sustainability of the transfer of knowledge throughout the industry via university interface.

The work also promotes the idea that the best way to leverage TH interactions is through the governance and policy intervention regional level, whose appropriate intensity can promote the stakeholder synergies and coalitions emergence thereby promoting spillover effect.

It is noteworthy from the article's point of view that the TH context thus emerges at regional level as a stakeholder forum between local companies, education providers and authorities and administrative agencies.

This approach sought to explain the interpellations richness on the theme and to emphasize the three spheres intertwining - government, educational institutions and society at large, composed by individuals, organizations and enterprises, with a common purpose in designing, reinventing and meeting human needs through knowledge and new technologies to rationalize the finite natural resources consumption and preserve nature.

A small Brazilian municipality called Santa Rita do Sapucaí, located in the southern region of the State of Minas Gerais - Brazil, was the search locus. This region emerges as a strong industrial vocation and vast educational activity in several knowledge areas based on the people intellectual growth, in support entrepreneurship and job creation.

For the purpose of this work, we construct the following research question: how can a business incubator contribute to the formation of an industrial cluster and to socioeconomic development in its geographic area of influence?

To obtain answers to this question, the general objective was to describe and analyze the business incubator's trajectory as the link between the Entrepreneurship Center of the National Institute of Telecommunications INATEL, in Brazil, and its results obtained by its own incubation program over 30 years (Instituto Nacional de Telecomunicações, 2017).

Special attention was given to the results obtained by the incubator by means its interaction with the other elements of the system, promoting befitting and updated training, capable of guaranteeing a consistent basis for the development and implementation of ideas, creation of business, vocational development of students and members of the community.

For this purpose the basic inductive research method was applied, with combined approaches and exploratory and descriptive purposes. The technical procedures used were the bibliographical survey, documentary analysis, field research and case study (Bertrand \& Fransoo, 2002; Beverland \& Lindgreen, 2010; Yin, 2015).

We expected that this research contributes to the academic literature aimed at entrepreneurship and business incubation centers and demonstrates the importance of establishing a resilient link between educational institutions and productive clusters. For business incubator's managers will be presented a set of successful actions and programs, proven by the performance and results of a Brazilian business incubator.

We have structured this article as follows: Section 2 presents the literature review discussing the constructs encompassing the triple helix model, business incubators and clusters. The research method is demonstrated in Section 3. In section 4 are presented the case study and the results. Concluding, in the Section 5, the discussions and final considerations were drawn up, followed by the bibliographic references.

\section{Background review}

\subsection{The Triple Helix model as an integrating system}

The Triple Helix Model (TH) is an innovation and entrepreneurship ecosystem of endowed with actors and institutions, links and functions (Nyman, 2015) from many institutional spheres (Etzkowitz, 2016). However, the TH structure can be broadened using the TH space notion, where synergistically the university, government and industry's institutional spheres of interact and co-evolve continuously (Etzkowitz \& Ranga, 2010).

Brem \& Radziwon (2017) suggest that in the triple helix model, local government agents try to support regional development by encouraging collaboration among various social actors. These actors consist primarily 
of local companies, universities, and government institutions, and their main supporting role is to focus on enhancing innovation-related activities, helping scholars better understand the dynamics of relationships between universities and their environments.

Recognizing that globalization stands out in the scientific publication field, when compared to the economy location in terms of wealth retention, it is inferred by the Leydesdorff \& Park (2014) approach that development and apply knowledge at the generating locus through activities productive processes based on R\&D, contributes to local economy strengthening, allowing better operationalization of required exchanges by the globalized economy mechanism. In this sense, these authors emphasize that metropolitan areas can provide the greatest synergy because they combine the location and globalization advantages in the micro-cosmos.

Inside TH model, the public and private actor's interaction is seen as essential for the improvement of socioeconomic conditions and to enable the emergence of innovations based on knowledge.

This hybrid model emphasizes the construction of overlapping and relatively interdependent relationships among its members. The model is a network that encourages the movement towards mutual collaborative relationships and linkages between the three major institutional spheres and several other organizations where innovation policy is the result of their interactions rather than government revenue (Sarpong et al., 2017).

In summary the $\mathrm{TH}$ concept, refers us to a neo-institutional model to study the cooperative network arrangement between the three different types of public and private spheres members in the relations between university-industry-government. Such a model is characterized by its neo-evolutionary function operating with emphasis on the relations between latent functions and networks (Strand \& Leydesdorff, 2013).

The model assumes that the economic development driving force in the post-industrial phase is no longer manufacturing, but rather the production and dissemination of socially organized knowledge. Knowledge-generating institutions increasingly play a role in the networks relationships between key actors: University (Science), Industry (Business) and Government (Governance).

These activities spheres are increasingly overlapping, and in intersection areas. According Leydesdorff \& Ivanova (2014), actors can partially replace each other. It is observed that the model has become omnipresent and internationalized, even though the institutional structures that support it remain specific to each country.

Danson \& Todeva (2016) proposed the dynamics of operation and regional Triple Helix expected results as exposed in Figure 1.

\begin{tabular}{|c|c|c|c|c|}
\hline \multicolumn{5}{|c|}{ Basic Regional Triple Helix Structure Model } \\
\hline $\begin{array}{l}\text { Regional Education } \\
\text { providers }\end{array}$ & \multicolumn{3}{|c|}{ Regional Government } & Local industry capabilities \\
\hline Research projects & \multicolumn{3}{|c|}{ Measure country impact } & \multirow[b]{2}{*}{ Innovators } \\
\hline $\begin{array}{l}\text { Universities and } \\
\text { research institutes }\end{array}$ & \multirow{5}{*}{$\begin{array}{l}\text { Research } \\
\text { excellence }\end{array}$} & $\begin{array}{l}\text { Country } \\
\text { structural } \\
\text { funds }\end{array}$ & \multirow{5}{*}{$\begin{array}{l}\text { Innovation } \\
\text { outputs }\end{array}$} & \\
\hline STI infrastructure & & $\begin{array}{l}\text { Regional } \\
\text { policies }\end{array}$ & & $\begin{array}{l}\text { SME linkages and } \\
\text { entrepreneurships }\end{array}$ \\
\hline \multirow{2}{*}{$\begin{array}{c}\text { Innovation and } \\
\text { technology transfer } \\
\text { networks }\end{array}$} & & \multirow{3}{*}{$\begin{array}{l}\text { Cross- } \\
\text { regional } \\
\text { comparisons }\end{array}$} & & Intellectual assets \\
\hline & & & & \multirow{2}{*}{ Economics effects } \\
\hline Training for research & & & & \\
\hline Skills and human capital & \multicolumn{3}{|c|}{ Public sector finance and support } & $\begin{array}{l}\text { Private sector investments } \\
\text { in R\&D }\end{array}$ \\
\hline & Faci & tors and $\mathrm{S}$ & orters & \\
\hline
\end{tabular}

Figure 1. Drivers of Triple Helix dynamics. Source: Adapted from Danson \& Todeva (2016).

Figure 1 provides a synthetic representation of the variety of actors, resources, and implemented activities that drive change and suggests some of the issues inherent in this shuffled and competitive phase.

This set of actors and policy measures in the context of interdependence, endogenous growth and reliance on bottom-up regeneration initiatives progressively encouraged subnational regions and territories to formalize their approach to economic development and competitiveness.

Under the theme 'Building Consensus Space and Who Should Lead Helix Triple', Todeva \& Ketikidis (2017) emphasize that the new business development and implantation (EDIP) model encompasses interregional implementation and requires a new type of government intervention, called by some authors 'entrepreneurial government'. 
These authors point out that in order to fulfill this function, active governments should make a more detailed industry and regional capacities mapping, create a communication platform for intersectoral and cross-border stakeholders that can engage industry-university and government (triple helix), guiding them to elaborate business models in commodity and value-added markets, considering the value chain creation aspect.

Kobza \& Mutlucan (2016, p. 291) emphasize that

[...] networks of relationships can provide not only resources and support, but also new and more holistic perspectives, thanks to different perspectives and members contributions. And add, [...] Today, the entrepreneurial mindset is often derived from young professionals and students. In addition, this mentality can be multiplied by the impact of their networks.

According to Kapetaniou \& Lee (2017), the universities current role in the knowledge-based economy can be analyzed using the TH. This analytical framework, which emphasizes the critical role of interactions between universities and other actors, can conceptualize their current role in the innovation process.

These initiatives are perceived as necessary conditions to strengthen the link between the constituent agents of $\mathrm{TH}$, in order to provide a basis for the construction of projects aimed at the idealization, development of innovations in the field of products and services directed to increasingly competitive markets.

Concerning the construction proposed by Kobza \& Mutlucan (2016); Kapetaniou \& Lee (2017), it can be noticed in the communities that integrate the Brazilian Electronics Valley the interaction governmental, business, and academic means.

Support and development institutions committed to local development, participate in capital contributions, project financing, economic feasibility analysis studies, consultancy and information, development and innovation, theoretical study and entrepreneurship practices.

In the discussion of the Triple Helix model, the most sustainable innovation model, Valente (2010) describes Etzkowitz's point of view when asked about the time-lag between government-university-industry, thus summarizing:

[...] they walk in different steps and occupy different spaces. And he adds: [...] Usually it takes an organization or an individual, who has the respect of all, to unite them in a profitable discussion, what 1 call 'spaces of consensus', for coordinate the relationships and ideas for a common project and improve the innovation system, be it in a region, state, or country.

\subsection{The Triple Helix Model and the local cluster}

As perceived in the surveyed locus, the solidification of the enterprises in a locality gain reinforcement when, they are installed in the form of local productive arrangements and begin to experience the model of cooperation and mutual, integration whose main effect is the strengthening of the whole by actions of greater attention and direction of public policies of development.

In line with the concept of the Triple Helix, it is observed in the region of the Valley of the Electronics the occurrence of a dynamics favorable to innovation as a propitiator of the sustainability of the initiatives directed to the processes of idealization, incubation, development and availability to the market of technology based solutions.

In this sense, it is possible to see in the communities that integrate the Valley of the Electronics the interaction of the governmental, business and academic means. Committed to local and regional development, support and development institutions participate through capital contributions, project financing, economic feasibility analysis studies, consultancy and information, development and innovation, theoretical study and entrepreneurship practices.

Among the supportive and formative initiatives of the local Triple Helix are: public power, financial development institutions, electronics cluster industries, technical schools, engineering colleges, administration and information systems.

The local electro-electronic cluster is made up of 153 companies, with the presence of 89 technology-based companies, of which 45 are graduates of Inatel's Incubator, working in the areas of development, manufacturing, trade, import and export of mechanical, electrical and electronic, telecommunication and computer system, broadcasting, remote management, internet access device, telecommunication security and authentication in systems of financial movement via Internet banking, electronic monitoring satellite systems, consulting and training. 


\subsection{Clusters: concepts and characterization}

In seeking to define cluster models by the 'triple helix' and their competitive advantage, Fundeanu \& Badele (2014) in their research about the impact of innovative regional clusters on competitiveness in the Oltenia region, southeast of Romania, emphasize that the cluster concept in development is a modern version of the growth pole concept.

The cluster is a companies and industries concentration in a geographic region, interconnected in the markets that they serve by the products that they manufacture, also acting in interaction with other regional actors. To support the clusters, public policies should consider private actors advantages and natural antecedents when proposing public investments, without forcing them to establish themselves in places that aren't aligned with their expertise.

Among the main findings of Fundeanu \& Badele (2014), it is possible to understand that the impact of the innovative cluster in the region where it is inserted can be observed for its contribution to the productive growth of the constituent company, to generate shared innovation, new business emergencies and expansion.

By working in clusters, companies, through cooperative actions, they have easier access to specialized inputs and technologies. The long-term performance of the cluster depends, among other things, on attracting companies, venture capital and new skills. Even when clusters sometimes incur high costs (e.g. labor or land), clusters stand out by creating innovations, developing resources and strong business relationships at home and abroad.

The developing economy, according to Prajova et al. (2014) perception requires constant changes in terms of innovations, where the science areas, business innovation and educational services are perceived as management paradigms removers. Economic efficiency will be determined first with the use of highly skilled specialists, new knowledge and skills, technologies and management techniques.

In addition to these authors' perception, the educational reform slowness, faced with new business environment demands has imposed a slow pace in improving the innovation systems efficiency, by maintaining an inadequate professional skills level in terms the development of scientific and methodological tools, to reconcile the interests of innovation in a particular way in the industrial clusters environment.

It emerges as the clusters importance lies in its capacity to increase the company's productivity and competitiveness vis-a-vis domestic and foreign economies, and also internationally. Specifically, clusters promote the use of scientific and technological development results, increase specialization, qualify employment, support new business initiatives (start-ups), create economies of scale, and make common marketing policy use.

Clusters also provide benefits for educational institutions by bringing dual education possibility based on theory and practice as well as applied research and technology transfer. These industrial agglomerates also generate significant economic benefits for the regions, together with infrastructure development.

The business clusters emergence is caused by globalization. To maintain success against competitors, companies must constantly launch new and better products meeting the required quality and technology standards. Only very innovative and flexible companies with enough knowledge can survive, as pointed out by Schmidt et al. (2016).

It is ascribable to Nemova et al. (2015), that for the full cluster formation is necessary to achieve a certain critical mass of participants (number of firms), comprised with common efforts to achieve synergies focused to the transition from quantity to quality.

The high connectivity level (cooperation) is one of the key factors in the cluster successful development. It represents a synergistic form as a sine-qua-non condition for the recognition in the cluster the high density links presence between organizations, united in a single activity site, as well as with other regional economy actors.

The cluster longevity requires, among other things, the concentration of innovative companies. Innovative activities require continuous improvement practices of competitive advantage through different types of innovation: technological, organizational and commercial. In this sense, the complete cluster must take precedence over these three types of innovation considering them dependent on each other (Nemova et al., 2015).

In terms of transaction cost theory, Schmidt et al. (2016) asserts that clusters of firms try to use the advantages of hierarchy and the market in extreme ways, organizing and sharing the expertises between them and thus including elements of cooperation and competition.

It can be seen in Janasová et al. (2017) that every enterprise operates in a particular environment. Enterprises are affected by this environment directly or vicariously. The enterprises are affected by several factors from internal and external environment. These factors can have a positive as well as negative character. 
Positive factors that affect small and medium enterprises (SMEs) are associated mainly with their indoor environment. SMEs have a simpler organizational structure, closer relationships with customers and are able to react more flexibly to market changes.

External barriers have the same effect on every business. SMEs have a low potential to change these barriers minimally. Most of these barriers increase costs for SMEs and are composed of price, marketing and market position and are mainly associated with the control over prices of raw strategic materials and exchange rates.

SMEs should focus on areas with the aim of strengthening and influencing in some way the minimization of the harmful effects of such barriers which can regulate in some way.

A good guideline for SMEs is the choice for quality rather than quantity. Regular market research should be a constant activity of SMEs. In general, they have limited resources. Therefore, it is very difficult, alone, to face these barriers and risks. Clustering is advantageous in view of risks minimization and the financial demands.

In analyzing the cooperation level among 381 companies and their contribution to strengthening it in the near future, Wasiluk (2017) reports that there is a large deficit in terms of both the existing cooperation and the willingness to strengthen it in the near future. The impact of the factors identified, pro-innovation, both at the level of current cooperation and in actions to strengthen it in the short term, was weak.

From the point of view of the formation and development of effective clusters links, the results were not optimistic. This author stated that the simple creation of a cluster does not release its innovative potential. To make real this condition, mutual openness is necessary to establish cooperation with all its actors, including competitors.

\subsection{Characterization of the industrial cluster of Santa Rita do Sapucai}

The Industrial Cluster of Santa Rita do Sapucaí has 153 companies, 44\% of companies operate less than $\$ 50,000$ a year, $90 \%$ are considered micro-enterprises and $8 \%$ are medium-sized enterprises. Total annual revenue is over $\$ 500$ million a year, generating around 14,000 jobs.

The companies invest, on average, $9 \%$ of the revenue in $\mathrm{R} \& \mathrm{D}$, percentage higher than the one verified for the biggest companies of computer science and telecommunications. The main products lines developed and produced in the industrial cluster are telecommunications, information technology, industrial automation, industrial equipment and services.

In general, the companies destine their products, preferably, to the internal market. About 34\% of them sell regularly to the international market, with the main customers being the MERCOSUR countries, which corresponds to $32 \%$ of the volume exported.

As for potential foreign markets, South America is seen as the most promising, then Central America and the Caribbean. With the support of consortia and integrated export support projects, since 2002 Valley of Electronic started an intensive internationalization program and increased the competitiveness of its companies. In 2011, the volume of exports reached 12 million dollars.

The 153 companies operating in the cluster have as common characteristic the constant search for innovation and the pioneering in the development of the more than 14,500 items that they manufacture. Its products are mainly focused on the following sectors: Electronics, Telecommunications, Security, Informatics, Broadcasting, Industrial Automation, Building, Information Technology, Supplies and Services.

The entire development of the local cluster is linked to the teaching of Electronics, Telecommunications, Information Technology and Administration, having as main characteristics the entrepreneurship and incentive to technological innovation.

The training and qualification of local professionals is promoted by pioneering institutions such as the Francisco Moreira da Costa Electronic Technical School (ETE), the first in Latin America (1959), the National Institute of Telecommunications Inatel (1965), the Center of Higher Education, Management, Technology and Education - FAl (1971) and SESI / SENAl - institution that promotes education and innovation for the industrial sector (2002 - in Santa Rita do Sapucaí).

\subsection{Business engineering incubators}

By characterizing business incubators as an interface between TH's other agents, can be seen, as pointed out Park \& Leydesdorff (2010), that the effectiveness of government intervention, however, should not be taken for granted. Systems are expected to have resilience following their own institutional logic, in the case of academia, and be guided by market forces in the case of industry. 
The purpose of the incubator is, in general, to establish a link between knowledge generated in the academy, technology developed during incubation programs, capital from sponsors or investors to supply the innovation process as a fundamental basis for entrepreneurs to create new business (Table 1). Passage through the incubator is seen as an important phase between breeding and maturation so that companies can graduate and consolidate in the market.

Table 1. Incubation program basis.

To stimulate the entrepreneurial spirit of the academics and alumni, to improve the professional qualification of the
engineers trained by it, to support the emergence and development of companies and products through the incubation of
technological-based enterprises
The Program is conducted by a manager appointed by the coordinator of the entrepreneurship center.
To promote the selection of projects between the proposals made by alumni and current scholars to research or
Goals $\quad$ development, or demonstrating the possibility of become products or services, or with specific perspectives to be produced or
used in industrial scale.

Source: Prepared by the authors.

Incubated companies, such as tenants, benefit from the common resources available in the business incubator, while renting the space with the shared resources. In this way, indirect costs are reduced: First, each tenant shares simultaneously the space, along with the resource package, such as: energy, water, telecommunications and cleaning. Second, the incubator offers services that are needed for the business in the early stages of development, such as: meeting rooms, reception services and private parking spaces. Third, this sharing also eliminates the burden of planning and deploying individual structures. In this way the incubated companies do not consume time with the administration of these complementary services, allowing them to concentrate on their core business. Finally, the shared use of spaces and resources discards spending during the difficult embryonic period of new enterprises (Bruneel et al., 2012).

It emphasizes the Gem (Greco, 2015, p. 92): “[...] it is necessary to implement ecosystems and transversal entrepreneurship centers that stimulate events deployment, courses, games, competitions, maker spaces, integration with companies / incubators / accelerators, and strong use of innovation environments / laboratories."

When referring to the learning processes: exploration, transformation and exploration, Ferreras-Méndez et al. (2016) suggests that, to develop exploratory learning, it is necessary to establish the maximum possible relationships with external agents. For the authors, in the case of exploratory learning, companies should be selective in establishing broad and deep connections with external agents.

The importance of the role played by business incubators, when they use their structural resources to promote the exchange of experiences between those entrepreneurs who are already established in the market, the educational agents and the beginners in the art of creating and developing business, is perceived.

It is inferred from Cantù (2017) that the business knowledge scattering is activated through the interface between the incubator and its main business partners and expanded to the other $\mathrm{TH}$ members in the form of a mediated relationship incubator (Figure 2).

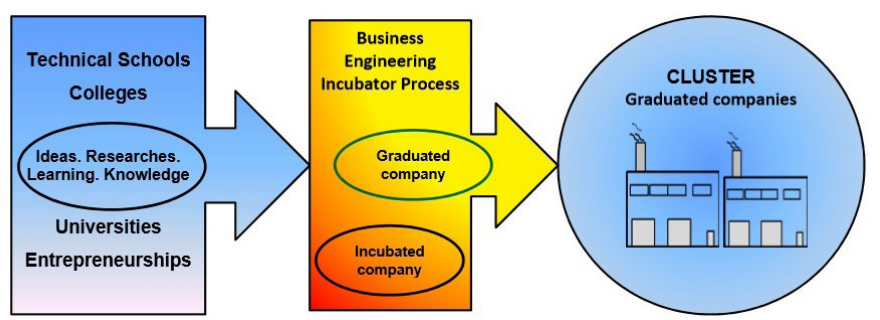

Figure 2. Incubator's promoted interface in the search locus. Source: Prepared by the authors.

The important role played by the incubator as a receptacle of ideas, research and knowledge has been perceived in the researched locus, through its incubation programs and consequent creation of new companies that, after graduation, as shown in Figure 2, are established in the local cluster or implanted in other regions, where they will perform their socioeconomic functions. 
By acting as a basis for preparing new businesses, the incubator as represented in Figure 2, through its incubation and graduation activities, is an essential part of the local innovation and entrepreneurship system.

Regarding business process management, Andrade et al. (2016) by proposing a strategic management method for the industrial companies' incubation process comments that business process management plays the main role within the industrial incubator management model.

The author emphasizes that this occurs because it includes the following basic business mechanisms: institutional support for companies, attraction of companies for the business, adaptation of companies to the specifics industrial incubator's implementation places, commercial aspects, legal issues, and mechanisms that define the roles of the company.

Kenney et al. (2013), seeking to understand how educational institutions can favor the social and technological development of localities, warn of the importance of national institutions to focus on entrepreneurship and development programs of technologies, as a way of gradually reducing dependence on external knowhow.

According to an economic impact study prepared by Anprotec (Associação Nacional de Entidades Promotoras de Empreendimentos Inovadores, 2016) "[...] in the case of Brazil, the relationship between incubated and graduated companies and local development can be reaffirmed by a rapid assessment of the profile of these enterprises."

Of the total number of companies incubated in the country, 96\% are micro and small companies, "[...] in the case of graduated companies this percentage is $85.9 \%$. These data reaffirm the local character of performance and contribution to the economic dynamics of the markets where these businesses are inserted" (Associação Nacional de Entidades Promotoras de Empreendimentos Inovadores, 2016).

\subsection{Business engineering incubators in Brazil}

The process of implanting business incubators in Brazil is recent. In spite of the rapid expansion presented up to 2009, the capacity to support technology-based companies is insufficient compared to the country's need, which presents a level of technological development incompatible with the requirements of developed markets.

Among the 384 Brazilian incubators in operation in 2016, 6.3\% were located in Minas Gerais State. The incubator mining movement stands out through robust programs aimed at technological development, which is evidenced by eight awards granted by the National Association of Entities Promoting Innovative Enterprises (Associação Nacional de Entidades Promotoras de Empreendimentos Inovadores, 2016).

As shown in Figure 3, Brazil is positioned ahead of some European countries when compared in terms of the survival rate of companies created from 2007 onwards.

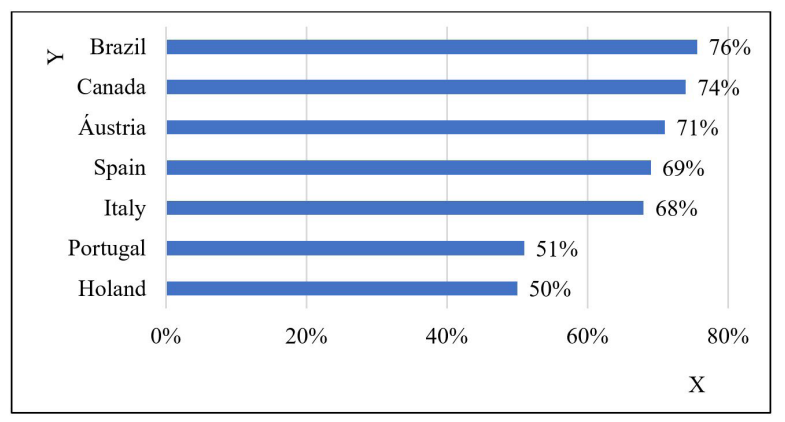

Figure 3. Survival rate of companies established since 2007 in selected countries. Source: Adapted from Faria \& Pires (2015).

Faria \& Pires (2015), it can be observed that the average survival rate of companies at national level, starting in 2007, is 75.6\%, with Minas Gerais State standing at 81\% survival - the highest rate in the country.

Inatel's Business Incubator has been contributing since its foundation in 1985 in the preparation of entrepreneurs during the incubation phase of their companies, as well as in the support and assistance to companies installed in the local electronic cluster.

Garcia et al. (2015) states that in the area of training and qualification of the workforce, one of the strengths of the local system is the importance of training human resources in electronics, mainly through lnatel.

Of the 58 companies formed by the Inatel's Incubator, 45 continue to develop their activities directly in the local electro-electronic cluster. This condition reinforces the high survival rate of companies graduated 
by its incubator and corroborates with the assertiveness of its entrepreneurship courses and new companies incubation programs.

This record of high local retention rate is unprecedented in the history of Brazilian incubation programs, whether related to private or public initiatives.

Table 2 shows an excerpt of publications that demonstrate the importance and recognition of Inatel"s business incubator contributions to the local cluster and neighborhood, from the perspective of entrepreneurs and local authorities.

Table 2. Interaction and importance of the incubator for the cluster.

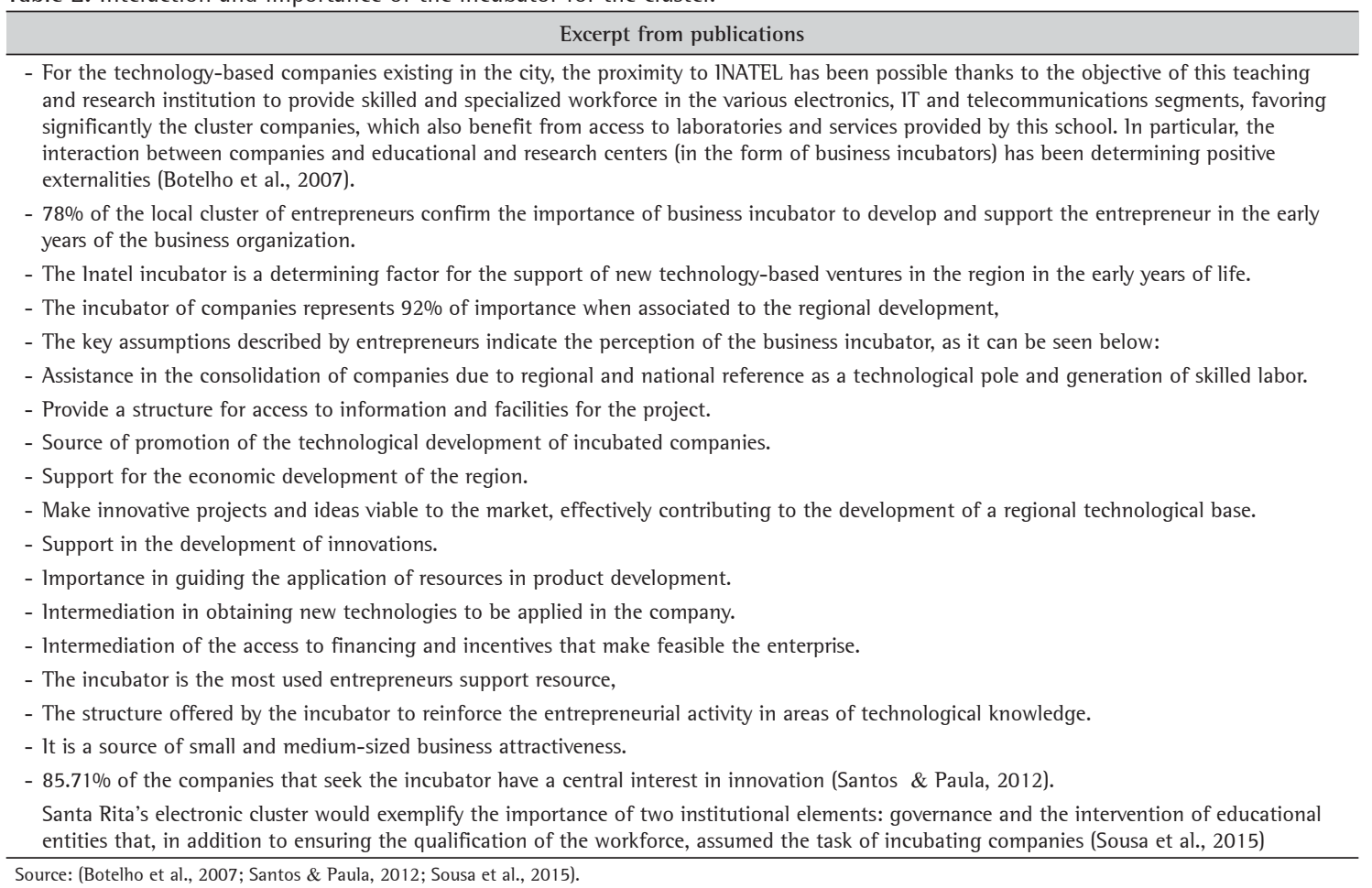

\section{Research method}

In this work, the inductive method of basic research was applied adding qualitative approaches and exploratory and descriptive purposes. The technical procedures used were the bibliographical survey, documentary analysis and field research (Figure 4).

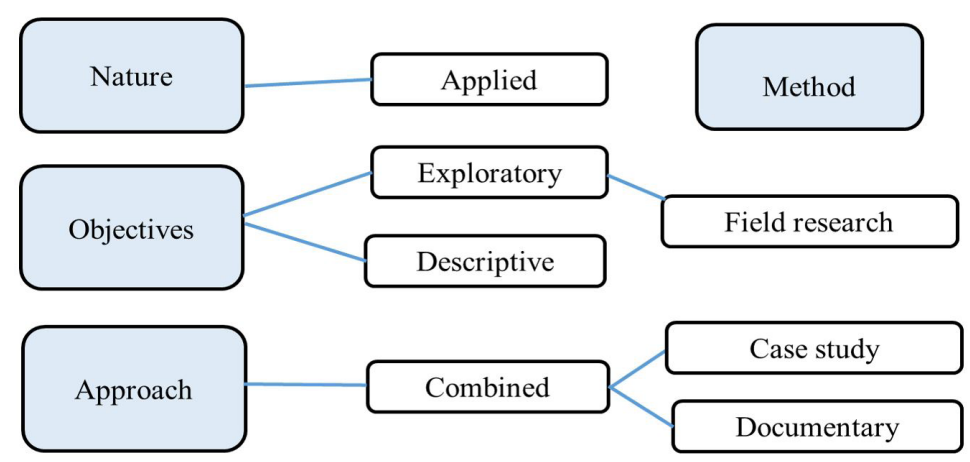

Figure 4. Graphical representation of the search method. Source: Prepared by the authors. 
The research was classified as applied nature with descriptive and exploratory objectives through field research. The combined approach was used applying the documentary methods and the case study.

Focusing on aspects related to the researcher's style and creativity, Easterby-Smith et al. (2012) emphasizes that the researcher needs to be on the move. Nobody trips over anything while sitting down. The greater, the curiosity, resilience and persistence of the researcher, the more likely he or she is to find something of significance.

From Bertrand \& Fransoo (2002) can be seen understood "[...] the scientific research essence is the real-life cases analysis, based on systematic observations. Quantitative relationships are based on a set of variables that vary in a specific domain, while quantitative and causal relationships were defined between these variables."

According to Miguel (2012) in the exploratory analysis for quantitative data, summary-measures can be calculated and classified into 'position measures' and 'measures of variability'. And it adds "[...] when it is desired to describe the quantity of interest succinctly, position measures and variability are used, such as mean, median, quartiles, variance, standard deviation and amplitude. Graphs are used to verify if the variable of interest obeys a normal distribution" (Miguel, 2012, p. 83).

The rationale for a single case study is its clear representativeness. The case study aims to generate context-specific knowledge; therefore, that research approach requires a tight structure to allow empirical data to be collected (Yin, 2015).

According to Creswell (2009, p. 220) for a sequential study, researchers of mixed methods usually organize the reporting of procedures in quantitative data collection and analysis of quantitative data followed by qualitative data. So, the author adds: Next, in the conclusions or in the interpretation phase of the study, the researcher measures how the qualitative information helped to elaborate or extend the quantitative results.

By referring to the investigative process as one of the bases for conducting qualitative and field research, Yin (2015) warns us that "[...] Because you are studying real-world events, they assume their own natural course and may present unanticipated resistances and challenges. You also may have to deal with embarrassing or difficult interpersonal situations" (p. 32).

Persevering means being able to move forward with your research in spite of all these encounters. "Naturally, you may reach a point when you are best advised to cease doing your study, and if you get to such a point you should consult with other people, such as colleagues and advisers, before throwing in the towel", affirms Yin (2015, p. 32).

Beyond the preceding personal attributes, the preparation to do qualitative research includes equipping yourself to manage field-based research. The kinds of field-based research vary. You may serve as a participant-observer in a real-world setting.

Doing such research requires recognizing that, inherent in the nature of the 'field', events are not within a researcher's control, nor would anyone wish that they were. Thus according to the perception of Yin (2015) "the challenge of managing field-based research is to attain some degree of meticulousness, but to avoid intruding into what is going on and to be able to tolerate occasionally high levels of uncertainty" (p. 33).

The author emphasizes the application of the method as an investigative process even when this limit "[...] faces a technically unique situation in which there will be many more variables of interest than data points and, as a result, is based on several sources of evidence [...]" (Yin, 2015, p. 33).

Depoy \& Gitlin (2015) states that to engage in the research process, the researcher identifies in advance a particular problem area or broad issues that require systematic investigation (p. 17).

\section{The case study}

The Inatel's Business Engineering Incubator offers a differentiated ambience for the creation and development of innovative technology-based startups and the results recorded throughout its existence justify its position among the best initiatives in the field of research, development and creation of innovations.

The incubator currently has nine resident companies (period from 2015 to 2017) and 58 graduated companies, together generating approximately 800 direct jobs and a revenue close to 70,7 million dollars a year.

In their facilities, incubated entrepreneurs receive constant support for business management focused on the structural areas of nascent companies, strongly marked by a modern business vision. Currently, the Innovation Network (RMI) considers the incubator researched as a reference among the initiatives of this segment that more companies graduate in the State of Minas Gerais.

The unit is 150 certified and has won two national awards from the National Association of Entities Promoting Innovative Companies - Anprotec, in 2005 (Best Project to Promote the Culture of Innovative Entrepreneurship 
in the Country) and 2014 (Best Business Incubator Focused on Local and Sectorial Development) (Instituto Nacional de Telecomunicações, 2017).

It is recorded, through the study conducted the occurrence of the interface between the companies graduated in the Entrepreneurship Center Incubator, here characterized as socio-productive agents, and, the National Telecommunications Institute - INATEL, the educational agent, when there is continuity of relations between graduate companies owners and business incubators, especially in the participation in activities developed by the Entrepreneurship Center, aimed at updating knowledge, research and development of products and services.

In addressing student persistence in advanced engineering regarding the interaction between university and industry, He (2017, p. 62) emphasizes: "[...] Both, the university and the collaborating companies should seize the opportunity for more communication with students". And adds "[...] the university could consider setting up a consulting and information system especially for distance students."

Still according to the author's approach

[...] Companies should play active roles in encouraging their employees to continue to study and create the atmosphere of positive learning. It is possible to infer from this construct, that participants of the same company, students of the same course can organize a study group, interacting in pairs aiming at obtaining a better result of study based on more discussions (He, 2017, p. 62).

This ideal proposed by He (2017) is perceived in the practice of the continued relationship after companies incubated graduation process in the Inatel's Entrepreneurship Center, whose graduates maintain long-lasting ties with the educational institution, in search of updating knowledge and exchanging professional experiences.

According to Table 3, the Inatel's business incubator participation contributed in 2016 to more than one fifth of the total graduated companies in the scope of the State of Minas Gerais.

Table 3. Performance of the INATEL business incubator in the state scenario.

\begin{tabular}{lccc} 
& Minas Gerais & INATEL & Participation of INATEL \\
\hline Number of incubators & 23 & 1 & $4.3 \%$ \\
lncubated companies & 146 & 11 & $7.5 \%$ \\
Graduated companies & 283 & 58 & $20 \%$ \\
\hline
\end{tabular}

Source: (Associação Nacional de Entidades Promotoras de Empreendimentos lnovadores, 2016; lnstituto Nacional de Telecomunicações, 2017).

Integrated to the Inatel's facilities set, the business incubator occupies a constructed area of 1,000 square meters and its facilities are composed as shown in Table 4.

Table 4. Incubator structure and resources.

\begin{tabular}{cc}
\hline Quantity & Spaces and Features \\
\hline 11 & Rooms of 30 square meters, intended for incubated enterprises \\
01 & Room of 25 square meters destined to the Junior Company \\
01 & Meeting room \\
01 & Library \\
04 & Training room, equipped with multimedia capabilities \\
05 & Rooms for the Pre-lncubation Program \\
01 & Rooms for the management team \\
01 & Prototyping laboratory \\
01 & Reception \\
01 & Living room \\
06 & Circulation area \\
\hline
\end{tabular}

Source: Instituto Nacional de Telecomunicações (2017).

\subsection{Findings}

Aiming to identify the business incubator contributions of that act as a link between the members of TH and an Industrial Cluster, the Entrepreneurship Nucleus of the National Institute of Telecommunications - INATEL, located in Brazilian's southeastern region was observation object (Figure 5). 


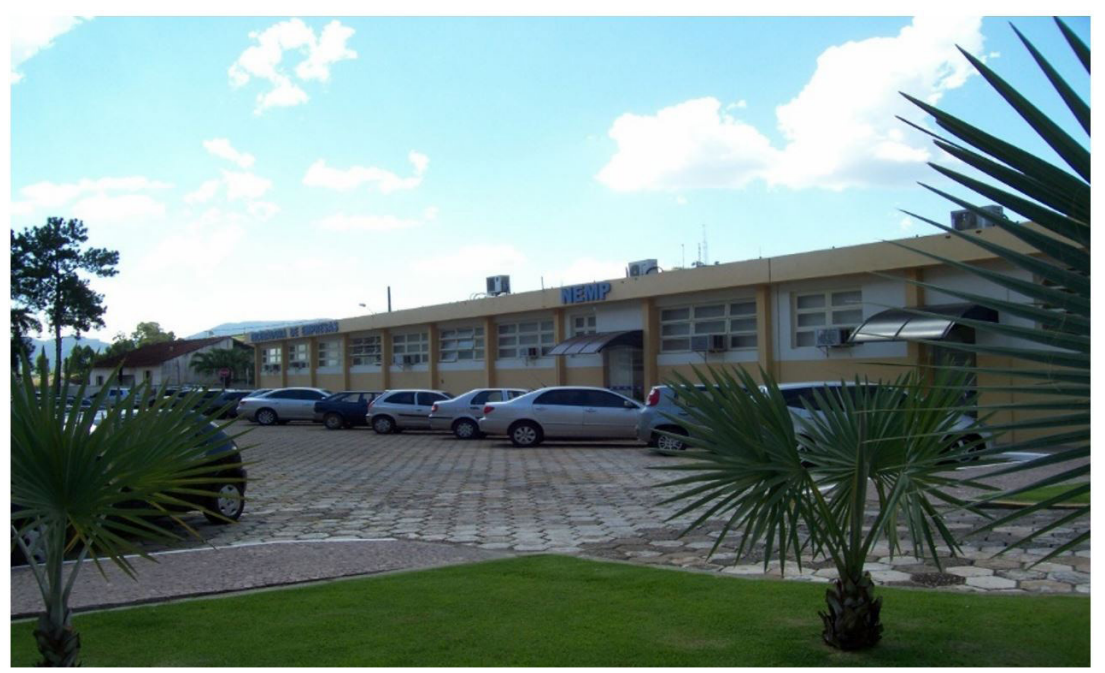

Figure 5. Business Incubator and Inatel Entrepreneurship Center - partial view Photo elaborated by the authors.

Specifically, our observations focused on incubation program performance and its results as an integral part of the Nucleus and Triple Helix agents established at the research locus.

Through exploratory, field and documentary research, it was verified that the Entrepreneurship Center, established in the researched locus is responsible for disseminating the entrepreneurial culture for students, teachers, employees and the local community.

The Inatel Entrepreneurship Center coordinates an academic program, which is a set of events and actions that aim to train entrepreneurs and stimulate the creation of small businesses. The Center acts directly in developments in the field of engineering, education and development of local and regional communities, through the following activities: Incubation of nascent companies; Olympiad of the Entrepreneur; Observatory of Entrepreneurs; Proposition of Challenges; Entrepreneur Week; Mileage Program; Laboratory of Ideation; Co-creation environment; Coworking environment; Bank of ideas and opportunities; Junior company; Global Entrepreneurship Week and Mentoring Program.

It can be seen, the wide range of activities, initiatives and contributions that gave the Entrepreneurship Center the highest awards and recognition of the segment evaluators. (Instituto Nacional de Telecomunicações, 2017). In the period between 1992 and 2017, there were 58 companies graduated in INATEL incubator, whose annual distribution is shown in the Figure 6.

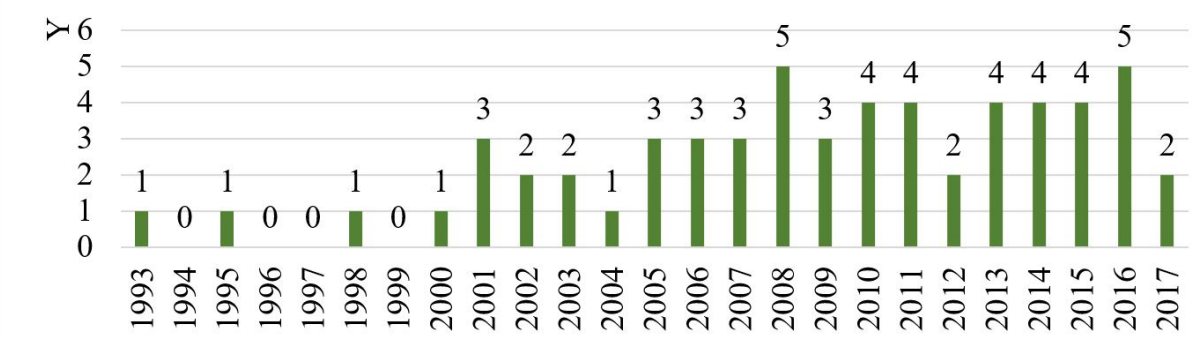

$\mathrm{X}$

Figure 6. Number of graduated companies in the incubator of Inatel - $1992-2017$. Source: Prepared by the authors.

According to Figure 6, the growth trend of the number of companies licensed by the Inatel's Entrepreneurship Center in recent years. The research realized by Anprotec (Associação Nacional de Entidades Promotoras de Empreendimentos Inovadores, 2016) demonstrates (Figure 7) the performance of the researched incubator, with the contribution of $21 \%$ of the total graduated companies in the 23 incubators in operation in the state of Minas Gerais. 


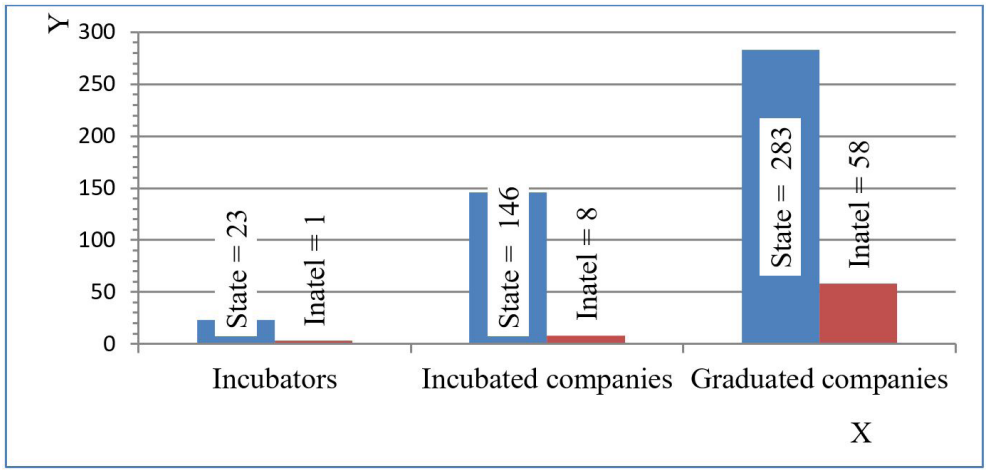

Figure 7. Performance of the INATEL incubator in the Minas Gerais State scenario. Source: Prepared by the authors.

It was highlighted in the study that the Brazilian Electronics Valley, locus researched, ranked 2nd among entrepreneur's cities with more incubators, surpassed only by the capital of Minas Gerais State.

In Table 5, it can be seen that the companies formed by the Inatel Entrepreneurship Center obtained high retention by the local cluster. As a result, $45(78.9 \%)$ of the 58 postgraduate companies remain active in the local industrial cluster. This reality allows us to infer the important contribution of the incubation program to the strengthening of the local economy in terms of job creation and tax retention in the municipality.

Table 5. Overall performance of the Entrepreneurship Center.

\begin{tabular}{cc}
\multicolumn{1}{c}{ Occurrences in the period 1992-2017 } \\
\hline Initial number of vacancies made available for incubation & 06 \\
Current number of vacancies for incubation of companies & 14 \\
Average number of candidates per job since foundation & 04 \\
Companies incubated since the creation of the incubator & 90 \\
Average number of graduated companies per year & 03 \\
Retention of incubated companies & $64.5 \%$ \\
Total number of students participating in incubation programs & 350 \\
External entrepreneurs in incubation programs & 60 \\
Jobs in the incubator & 1,000 \\
Trainees developed in the incubator & 700 \\
Total of graduated companies & 58 \\
Graduated companies working in the local cluster & 45 \\
\hline
\end{tabular}

Source: Prepared by the authors.

In Table 6 are the observations by Dionísio (2009); Faria \& Pires (2015) and Anprotec (Associação Nacional de Entidades Promotoras de Empreendimentos Inovadores, 2016) on the evolution of the mortality and survival rate of companies at the Brazilian and Minas Gerais State levels.

An important aspect of the performance of the researched incubator can be observed in Table 6, when it was verified its percentage of success in terms of survival of graduated companies. It also is shown that companies created without insertion in incubation programs differ from the companies incubated in the Brazilian Electronics Valley, specifically in the researched incubator, showing a favorable percentage of $14.4 \%$.

Table 6. Percentage of mortality (failure) and survival (success).

\begin{tabular}{ccc}
\hline SCOPE OF RESEARCH & MORTALITY (Failure) & $\begin{array}{c}\text { SURVIVAL } \\
\text { (Success) }\end{array}$ \\
\hline ALL COMPANIES IN GENERAL & $24.4 \%$ & $75.6 \%$ \\
Research conducted by the Brazilian Micro and Small Business Support Service & & \\
COMPANIES BORN BY INCUBATOR SYSTEM & $20 \%$ & $80 \%$ \\
Associação Nacional de Entidades Promotoras de Empreendimentos inovadores - ANPROTEC & $12 \%$ & $88 \%$ \\
Municipal lncubator & $10 \%$ & $90 \%$ \\
Research incubator & & \\
\hline
\end{tabular}

Source: Prepared by the authors. 
It is concluded from this observation that the graduated companies in Inatel's Entrepreneurship Center demonstrate better performance, when compared to other undergraduate programs at the local, state and national levels (Table 7).

Table 7. Incubator performance awards.

\begin{tabular}{cc} 
Year & Awards \\
2005 & Anprotec Award - 'Best Incubation Program for Innovative Entrepreneurs in the Country' and 'Best Project to Promote the Culture of \\
2005 & Student Guide Award - Best Universities - Entrepreneurship \\
2012 & Finep lnnovation Award - Brazil's most innovative 1CT \\
2013 & Santander Universities Award Student Guide - partnership with the private sector \\
2014 & Anprotec Award - Best Business Incubator focused on local and sectorial development \\
2015 & Santander Universities Award Student Guide - Highlights of the Year - fundraising \\
2016 & Mobilizing lncubator Award - Bloombtech Program - initiative of SEBRAE-MG, RMl and Minas Gerais government. \\
\hline Source: Instituto Nacional de Telecomunicacones (2017).
\end{tabular}

\section{Conclusions}

We present a case study on the contributions of a business incubator that acts as a link between the members of the Triple Helix Model (TH) and an Industrial Cluster. We emphasize the incubator's trajectory and its results as an integral part of the triple helix model established in the locus researched. We investigated the Brazilian Electronic Valley, located in the southern state of Minas Gerais, Brazil.

We have shown the effective participation of the incubator in the composition and development of the local industrial cluster. In this sense, the main contribution of this work is the identification of a successful experiment in the practice of implantation of the triple helix model in Brazil. We emphasize the effectiveness of the work developed by the incubator, evidencing the expressive survival rate of the companies graduated in it.

We have expanded the current understanding of the role of business incubators, showing their effective participation in the socioeconomic development of the region in their environment. We have unleashed the role of Inatel, a national reference institution in technical and technological education in the high technology sector, through its incubator, by promoting the opening of technology-based ventures in the southern region of Minas Gerais, and consequently encouraging innovation and product creation, financial assistance and development partnerships, characterizing the city's vocation as a technological pole.

The low mortality rate of the companies graduated in the studied incubator indicates the consistency of the incubation program, whose survival rate of 90\% exceeded the Brazilian national average. However, there is instability in terms of number of graduates throughout the existence of the incubator, which encourages further research to identify the reasons for this oscillation.

The occurrence of interaction between the researched incubator and the local cluster was evidenced in the findings of the research, as well as confirmed in related publications, mainly through orientation and training programs of entrepreneurs in the local electro-electronic cluster.

Another proof of this incubator-society interaction was perceived by the continuous success of the incubation program, involving internal and external members of the educational institution, and the retention of 78.9\% of the companies graduated by the local cluster.

The on-site observations allowed us to identify how an institution of higher education in engineering can contribute to socioeconomic development in its geographic area of influence, applying the guidelines of the $\mathrm{TH}$ model. However, considering the restricted presence of its model in Brazil, it is opportune to suggest new studies that demonstrate the state of the art of this model in the context of the more developed world economies.

It seems appropriate to recommend that future research continue to investigate the modes and benefits of relationships between agents of the Triple Helix Model. We dare to believe that new researchers should focus on the institutional level to argue those who direct the sectors of government, educational institutions and the productive sector to the urgency of depriving themselves of the isolated interests of their corporations for the benefit of greater sharing knowledge and experience.

In reflecting on the success of the case being studied, it is likely that through it, they will find good ways to accelerate the process of sustained growth of the country's economy, making it more resilient to face the local and global market instabilities. 
Conscious of our limitations, it is plausible to suggest that the language applied by future researchers is more appropriate to the target audience and that their efforts transcend our primary research.

It is understood that, despite the limitations of the focus in an isolated case study, it is expected that its results will be useful as a starting point for future research that seeks to demonstrate the importance of cooperation networks between educational institutions, companies and government sectors.

Above all, this study is expected to elicit the reflection of individuals and organizations in general on the importance of creating interconnected and complementary cooperative networks with the aim of developing stronger local economies, more knowledge and progress for communities.

In conclusion, recognizing the limitation of the research, it is believed that this study contributed to demonstrate the importance of the work of business incubators as a link between educational institutions and society, and specifically in the activities of guidance to nascent companies, formation of industrial clusters and consequent contribution to job creation and economic growth. Hoping for future research, it is proposed: to deepen the study and the learning about the improvement of the competitiveness of the clusters through the application of the triple helix model.

\section{Acknowledgements}

This research was partially supported by The National Council for Scientific and Technological Development (CNPq - 306214/2015-6) and São Paulo Research Foundation (FAPESP - 2015/24560-0).

\section{References}

Andrade, L. P. C. S., Ferreira, C. V., Silva, R. C., \& Gomes, J. O. (2016). Strategic management method for the incubation process of industrial companies: case study of the tooling industry in Brazil. Procedia CIRP, 41, 129-134. http://dx.doi.org/10.1016/j.procir.2015.08.032.

Associação Nacional de Entidades Promotoras de Empreendimentos lnovadores. (2016) Estudo de impacto econômico: segmento de incubadoras de empresas do Brasil. Brasília: ANPROTEC/SEBRAE. Retrieved in 2017, October 27, from http://www.anprotec.org.br/ Relata/18072016\%20Estudo_ANPROTEC_v6.pdf

Bertrand, J.W.M., \& Fransoo, J. C. (2002). Operations management research methodologies using quantitative modeling. International Journal of Operations \& Production Management, 22(2), 241-264. http://dx.doi.org/10.1108/01443570210414338.

Beverland, M., \& Lindgreen, A. (2010). What makes a good case study? Industrial Marketing Management, 39(1), 56-63. http://dx.doi. org/10.1016/j.indmarman.2008.09.005.

Botelho, M. R. A., Carrijo, M. C., \& Kamasaki, G. Y. (2007). Inovações, pequenas empresas e interações com instituições de ensino/ pesquisa em arranjos produtivos locais de setores de tecnologia avançada. Revista Brasileira de Inovação, 6(2), 331-371. http:// dx.doi.org/10.20396/rbi.v6i2.8648951.

Brem, A., \& Radziwon, A. (2017). Efficient Triple Helix collaboration fostering local niche innovation projects - a case from Denmark. Technological Forecasting and Social Change, 123, 130-141. http://dx.doi.org/10.1016/j.techfore.2017.01.002.

Bruneel, J., Ratinho, T., Clarysse, B., \& Groen, A. J. (2012). The evolution of business incubators: comparing demand and supply of business incubation services across different incubator generations. Technovation, 32(2), 110-121. http://dx.doi.org/10.1016/j. technovation.2011.11.003.

Cantù, C. (2017). Entrepreneurial knowledge spillovers: discovering opportunities through understanding mediated spatial relationships. Industrial Marketing Management, 61, 30-42. http://dx.doi.org/10.1016/j.indmarman.2016.07.002.

Creswell, J. W. (2009). Research design: qualitative, quantitative, and mixed methods approaches (3th ed.). Thousand Oaks: SAGE Publications.

Danson, M., \& Todeva, E. (2016). Government and governance of regional Triple Helix interactions. Industry and Higher Education, 30(1), 13-26. http://dx.doi.org/10.5367/ihe.2016.0293.

Depoy, E., \& Gitlin, L. N. (2015). Introduction to research: understanding and applying multiple strategies. Oxford: Elsevier Health Sciences.

Dionísio, L. C. (2009). Empreendedorismo e processo de incubação: análise comparativa dos principais mecanismos influenciadores de sucesso nas empresas graduadas das incubadoras do vale da eletrônica (Trabalho de conclusão de especialização). Faculdade de Administração e Informática, Santa Rita do Sapucaí. Retrieved in 2017 March 12, from http://www.faimg.br/biblioteca/index. php?option=com_docman\&task=cat_view\&gid=110\&dir=DESC\&order=name\&ltemid=99999999\&limit=5\&limitstart=5

Easterby-Smith, M., Thorpe, R., \& Jackson, P. R. (2012). Management research. Atlanta: Sage.

Etzkowitz, H. (2016). Innovation lodestar: the entrepreneurial university in a stellar knowledge firmament. Technological Forecasting and Social Change, 123, 122-129. https://doi.org/10.1016/j.techfore.2016.04.026.

Etzkowitz, H., \& Ranga, M. (2010) A Triple Helix system for knowledge-based regional development: from "spheres" to "spaces". In Theme paper for Triple Helix 8 International Conference. Madrid: Triple Helix. Retrieved in 2017 Aug 12, from http://www. triplehelixconference.org/th/8/downloads/Theme-Paper.pdf

Faria, R., \& Pires, S. 0. (2015). Estudo, análise e proposições sobre as incubadoras de empresas no Brasil. Brasília: Anprotec. Retrieved in 2017 April 27, from: http://www.ntg.ufv.br/wp-content/uploads/Estudo-Incubadoras_MG_NTG_COMPLETO.pdf

Ferreras-Méndez, J. L., Fernández-Mesa, A., \& Alegre, J. (2016). The relationship between knowledge search strategies and absorptive capacity: a deeper look. Technovation, 54, 48-61. http://dx.doi.org/10.1016/j.technovation.2016.03.001. 
Fundeanu, D. D., \& Badele, C. S. (2014). The impact of regional innovative clusters on competitiveness. Procedia: Social and Behavioral Sciences, 124, 405-414. http://dx.doi.org/10.1016/j.sbspro.2014.02.502.

Garcia, R., Diegues, A. C., Roselino, J. E., \& Costa, A. R. (2015). Local development and industrial deconcentration: an analysis of the dynamics of the local system of electronic companies of Santa Rita do Sapucai and the implications of their policies. Nova Economia, 25(1), 105-122. http://dx.doi.org/10.1590/0103-6351/1713.

Greco, S. M. S. S. (Coord.). (2015). GEM: empreendedorismo no Brasil. Curitiba: IBQP. 178 p. Retrieved in 2017 April 27, from http:// www.bibliotecas.sebrae.com.br/chronus/ARQUIVOS_CHRONUS/bds/bds.nsf/4826171de33895ae2aa12cafe998c0a5/\$File/7347.pdf

He, J. (2017). Students' persistence in advanced engineering university-industry-collaborated distance education: a case study of the project 'expertise for sustainable wood construction' in Linnaeus University. Retrieved in 2017 March 18, from http://www.divaportal.org/smash/get/diva2:1119864/FULLTEXT01.pdf

Instituto Nacional de Telecomunicações. (2017). Instituto Nacional de Telecomunicações - Inatel. Santa Rita do Sapucaí: Inatel. Retrieved in 2017 March 13, from www.inatel.br

Janasová, D., Bobá $\square$ ová, V., \& Strelcová, S. (2017). Networking of small and medium enterprises into clusters in the slovak republic. Procedia Engineering, 192, 370-375. http://dx.doi.org/10.1016/j.proeng.2017.06.064.

Kapetaniou, C., \& Lee, S. H. (2017). A framework for assessing the performance of universities: the case of Cyprus. Technological Forecasting and Social Change, 123(1), 169-180. https://doi.org/10.1016/j.techfore.2016.03.015.

Kenney, M., Breznitz, D., \& Murphree, M. (2013). Coming back home after the sun rises: returnee entrepreneurs and growth of high tech industries. Research Policy, 42(2), 391-407. http://dx.doi.org/10.1016/j.respol.2012.08.001.

Kobza, N., \& Mutlucan, C. (2016). Entrepreneurship leading a change in Europe: a perspective of young professionals. IFAC-PapersOnLine, 49(29), 289-293. http://dx.doi.org/10.1016/j.ifacol.2016.11.081.

Leydesdorff, L., \& Ivanova, 1. A. (2014). Mutual redundancies in inter-human communication systems: steps towards a calculus of processing meaning. Journal of Association Informtion Science Tech, 65(2), 386-399. http://dx.doi.org/10.1002/asi.22973.

Leydesdorff, L., \& Park, H. W. (2014). Can synergy in Triple Helix relations be quantified? A review of the development of the Triple Helix indicator. Triple Helix, 1(1), 4. http://dx.doi.org/10.1186/s40604-014-0004-z.

Miguel, P. A. C. (2012). Metodologia de pesquisa em engenharia de produção e gestão de operações. Rio de Janeiro: Elsevier.

Nemova, D., Bagautdinov, R., \& Mushinskiy, A. (2015). University-business cooperation based on virtual research information service. Procedia Engineering, 117, 1115-1121. http://dx.doi.org/10.1016/j.proeng.2015.08.244.

Nyman, G. S. (2015). University-business-government collaboration: from institutes to platforms and ecosystems. Triple Helix, $2(1), 2$. http://dx.doi.org/10.1186/s40604-014-0014-x.

Park, H. W., \& Leydesdorff, L. (2010). Longitudinal trends in networks of university-industry-government relations in South Korea: the role of programmatic incentives. Research Policy, 39(5), 640-649. http://dx.doi.org/10.1016/j.respol.2010.02.009.

Prajova, V., Perminova, O., \& Faizullin, R. (2014). Principles of organizations' interaction while forming mechatronics specialists' professional competences in a regional industry cluster. Procedia Engineering, 96, 370-373. http://dx.doi.org/10.1016/j.proeng.2014.12.104.

Santos, 1. C., \& Paula, R. M. D. (2012). A especialização tecnológica local como indutora do empreendedorismo e do desenvolvimento regional: o caso do Vale da Eletrônica brasileiro. Gestão \& Regionalidade, 28(82), 65-82. http://dx.doi.org/10.13037/gr.vol28n82.1413.

Sarpong, D., Razak, A. A., Alexander, E., \& Meissner, D. (2017). Organizing practices of university, industry and government that facilitate (or impede) the transition to a hybrid triple helix model of innovation. Technological Forecasting and Social Change, 123, 142-152.

Schmidt, D. M., Böttcher, L., Wilberg, J., Kammerl, D., \& Lindemann, U. (2016). Modeling Transfer of Knowledge in an Online Platform of a Cluster. Procedia CIRP, 50, 348-353. http://dx.doi.org/10.1016/j.procir.2016.05.036.

Sousa, A. R. D., Brito, M. J. D., Silva, P. J., \& Araújo, U. P. (2015). Cooperação no Apl de Santa Rita. Revista de Administração Mackenzie, 16(1), 157-187. http://dx.doi.org/10.1590/1678-69712015/administracao.v16n1p157-187.

Strand, Ø., \& Leydesdorff, L. (2013). Where is synergy indicated in the Norwegian innovation system? Triple-Helix relations among technology, organization, and geography. Technological Forecasting and Social Change, 80(3), 471-484. http://dx.doi.org/10.1016/j. techfore.2012.08.010.

Todeva, E., \& Ketikidis, P. (2017). Regional entrepreneurship and innovation management: actors, helices and consensus space. Management Dynamics in the Knowledge Economy, 5(1), 57-76. http://dx.doi.org/10.25019/MDKE/5.1.04.

Valente, L. (2010). Hélice tríplice: metáfora dos anos 90 descreve bem o mais sustentável modelo de sistema de inovação. Revista Conhecimento \& Inovação, 6(1), 6-9. Retrieved in 2017 August 27, from http://inovacao.scielo.br/scielo.php?script=sci_arttext\&pid=S1984$43952010000100002 \& \operatorname{lng}=$ pt\&nrm=iso

Wasiluk, A. (2017). Pro-innovative prerequisites for establishing the cooperation between companies (in the perspective of creation and development of clusters). Procedia Engineering, 182, 755-762. http://dx.doi.org/10.1016/j.proeng.2017.03.195.

Yin, R. K. (2015). Qualitative research from start to finish. New York: Guilford Publications. 